\title{
Pengaruh Kepercayaan dan Kualitas Pelayanan Terhadap Loyalitas Pelanggan Pengguna Jasa Pengiriman Paket Pada PT. JNE Express Cabang Jember dengan Kepuasan Sebagai Variabel Intervening \\ (The Effect of Trust and Service Quality to Customer Loyalty Users Delivery Service Package in PT. JNE Express Branch Jember with Satisfaction as Intervening Variables)
}

\author{
Frizky Yuniarta*, Ika Barokah S, Gusti Ayu Wulandari \\ Jurusan Manajemen, Fakultas Ekonomi dan Bisnis, Universitas Jember (UNEJ) \\ Jln. Kalimantan 37, Jember 68121 \\ E-mail: ikifriz@yahoo.com
}

\begin{abstract}
Abstrak
Penelitian ini bertujuan untuk mengetahui pengaruh kepercayaan dan kualitas pelayanan terhadap loyalitas pelanggan pengguna jasa pengiriman paket pada PT. JNE Express Cabang Jember dengan kepuasan sebagai variabel intervening. Jenis penelitian adalah explanatory research. Populasi penelitian adalah semua pelanggan PT. JNE Express Cabang Jember yang pernah melakukan pengiriman paket. Metode pengambilan sampel dalam penelitian ini dilakukan dengan teknik purposive sampling dan diperoleh 120 responden sebagai sampel. Metode analisis data yang digunakan adalah analisis jalur/path. Hasil penelitian antara lain adalah hasil pengujian analisis jalur atas pengaruh kepercayaan terhadap kepuasan menunjukkan hubungan yang positif. Ini membuktikan bahwa semakin baik kepercayaan maka akan meningkatkan kepuasan. Hasil pengujian atas pengaruh kepercayaan terhadap loyalitas pelanggan menunjukkan hubungan yang positif. Ini membuktikan bahwa semakin baik kepercayaan maka akan meningkatkan loyalitas. Hasil pengujian atas pengaruh kualitas pelayanan terhadap kepuasan menunjukkan hubungan yang positif. Ini membuktikan bahwa semakin baik kualitas pelayanan maka akan meningkatkan kepuasan. Hasil pengujian atas pengaruh kualitas pelayanan terhadap loyalitas menunjukkan hubungan yang positif. Ini membuktikan bahwa semakin baik kualitas pelayanan maka akan meningkatkan loyalitas. Hasil pengujian atas pengaruh kepuasan terhadap loyalitas menunjukkan hubungan yang positif. Ini membuktikan bahwa semakin baik kepuasan maka akan meningkatkan loyalitas.
\end{abstract}

Kata Kunci: Kepercayaan, Kepuasan, Kualitas Pelayanan, Loyalitas.

\begin{abstract}
This study aims to knowing the influence of trust and service quality to customer loyalty users delivery service package in PT. JNE Express Branch Jember with satisfacton as intervening variables. This study is explanatory research. Population is all customer of PT. JNE Express whoever sent the package. The sampling method for this study was used with purposive sampling technique and it got 104 respondents as samples. Data analysis method is Path Analysis. The result of study showed that path analysis determined the influence of trust toward satisfaction showed positive relation. It indicates that the better trust could increase customer satisfaction. Path analysis determined the influence of trust toward customer loyalty showed positive relation. It indicates that the better trust could increase customer loyalty. Path analysis determined the influence of service quality toward satisfaction showed positive relation. It indicates that the better service quality could increase customer satisfaction. Path analysis determined the influence of service quality toward customer loyalty showed positive relation. It indicates that the better service quality could increase customer loyalty. Path analysis determined the influence of customer satisfaction toward customer loyalty showed positive relation. It indicates that the better customer satisfaction could increase customer loyalty.
\end{abstract}

Keywords: Trust, Customer Satisfaction, Service Quality, Loyalty.

\section{Pendahuluan}

Perkembangan bidang teknologi saat ini berdampak pada perekonomian Indonesia terutama pada bidang industri jasa. Hal ini terkait dengan semakin maraknya bisnis jual beli online yang dilakukan oleh pelaku usaha online yang terdiri dari masyarakat maupun perusahaan - perusahaan toko online. Bisnis jual beli online membutuhkan jasa pengiriman paket untuk mengantarkan barang dari toko online kepada konsomen dengan cepat, mudah dan aman baik didalam kota, luar kota maupun luar pulau. Perkembangan bisnis jasa pengiriman dalam negeri semakin meningkat, berdasarkan data Asperindo (Asosiasi Perusahaan Jasa Pengiriman Ekspres POS dan Logistik Indonesia) bahwa pertumbuhan jasa kurir di Tahun 2016 secara keseluruhan meningkat antara $20 \%$ sampai $30 \%$. Hal ini dikarenakan oleh pertumbuhan e-commerce dan kemudahan dalam memperoleh izin usaha dari pemerintah.

Yoga (2015) mengungkapkan dalam penelitiannya bahwa kepercayaan memiliki pengaruh yang signifikan terhadap loyalitas pelanggan. Hal ini berarti bahwa persepsi yang tinggi atas kepercayaan yang dimiliki seseorang akan meningkatkan loyalitas pelanggan. Menurut Reichheld dan Scefter (2000) untuk mendapatkan loyalitas konsumen bisnis harus mampu terlebih dahulu mendapatkan kepercayaan mereka. Kepercayaan (trust or belief) merupakan keyakinan bahwa tindakan orang lain atau suatu kelompok konsisten

\footnotetext{
* Corresponding author
} 
dengan kepercayaan mereka (Debholkar, Junusi dalam Yoga, 2015). Para pelaku bisnis online sebagai pengguna jasa pengiriman kini semakin selektif dalam memilih jasa pengiriman hal ini di akibatkan karena tingkat pilihan pada industri jasa pengiriman semakin tinggi serta peristiwa atau kasus hilangnya barang atau paket milik pelanggan, sehingga suatu perusahaan jasa pengiriman harus mampu menciptakan kepercayaan kepada pelanggannya, yaitu dengan cara menjamin barang dari pelanggan tersebut sampai ke pihak yang dituju dengan keadaan utuh. Mitel et al. (dalam Yoga, 2015) menyatakan bahwa kepercayaan konsumen terhadap suatu produk atau jasa akan tumbuh apabila memiliki pengalaman dan informasi yang baik.

Kotler (2006:177) menyatakan bahwa kepuasan pelanggan adalah tingkat perasaan seseorang setelah membandingkan kinerja atau hasil yang ia rasakan dibandingkan dengan harapannya. Dari definisi tersebut dirumuskan sebagai penilaian oleh konsumen setelah pembelian atau penggunaan jasa, bilamana persepsi terhadap kinerja alternatif produk/jasa yang dipilih memenuhi atau melebihi harapan sebelum membeli. Pada perusahaan jasa pengiriman diera saat ini dimana pelanggan memiliki harapan-harapan yang harus dipenuhi oleh perusahaan jasa pengiriman apabila menginginkan pelanggannya terpuaskan. Steven (2014) menyatakan dalam penelitiannya mengemukakan bahwa kepuasan pelanggan memiliki hubungan yang signifikan terhadap loyalitas pelanggan. Hal ini menunjukkan bahwa kepuasan yang dirasakan oleh pelanggan mampu membentuk pelanggan menjadi semakin loyal. Menurut Kotler dan Keller (2009:138), mengungkapkan loyalitas adalah suatu komitmen yang dipegang secara mendalam untuk membeli atau mendukung kembali produk atau jasa yang disukai di masa yang akan datang meski pengaruh situasi dan usaha pemasaran berpotensi menyebabkan pelanggan beralih.

Berdasarkan data Asperindo bahwa salah satu perusahaan jasa pengiriman yang ada di Indonesia adalah JNE Express. JNE Express merupakan salah satu perusahaan pengiriman jasa yang melayani pengiriman paket dan dokumen tujuan dalam negeri melalui lebih dari 1.500 titik layanan ekslusif dari penjemputan hingga pengantaran yang tersebar diseluruh Indonesia. JNE Express bisa dikatakan perusahaan pengiriman terbesar di Indonesia karena JNE Express membuka beberapa cabang di kota-kota besar yang ada di Indonesia salah satunya ialah JNE Express Cabang Jember. Berdasarkan observasi yang telah dilakukan bahwa di Jember, bisnis online banyak dilakukan oleh kalangan masyarakat maupun mahasiswa, mereka melakukan bisnis online melalui beberapa media, seperti memasang produk yang dijualnya di toko online maupun sosial media seperti facebook, twitter, BBM.

Berdasarkan observasi terhadap pelanggan PT JNE Express Cabang Jember bahwa terdapat kasus hilangnya barang dan rusaknya barang, hal ini berpengaruh terhadap kepercayaan pelanggan terhadap PT JNE Express Cabang Jember. Dengan adanya fenomena tersebut berdampak terhadap kepuasan pelanggan, pelanggan menunjukkan rasa tidak puasnya dengan menceritakan di media sosial mengundang banyak tanggapan negatif dari orang yang pernah memakai jasa JNE Express Cabang Jember. Di sisi lain juga pelanggan menjadi tidak loyal karena ketidakpuasan yang mereka rasakan, mereka memilih beralih ke perusahaan jasa pengiriman lainnya. Dari berbagai kasus tersebut, PT JNE Express Cabang Jember harus mencari cara agar tingkat kepercayaan pelanggan serta kualitas pelayanan dapat diperbaiki yang bertujuan untuk menciptakan kepuasan pelanggan yang mengarah terhadap loyalitas pelanggan.

Upaya untuk meningkatkan kepuasan dan loyalitas bukan hal yang mudah. Hal ini disebabkan ada beberapa perusahaan jasa pengiriman paket yang sejenis seperti PT POS Indonesia, PT TIKI, Indah Cargo, Platinum Logistic, PT Kereta Api Logistic, J\&T Express dan lainnya. Kondisi semakin banyak perusahaan jasa pengiriman paket di Jember maka semakin besar pangsa pasar yang diperebutkan, sehingga tingkat persaingan bisnis semakin ketat antar perusahaan jasa pengiriman paket. JNE Express mengalami naik turun dalam persaingan sesama perusahaan jasa pengiriman di Indonesia termasuk di Jember. PT JNE Express saat ini yang menduduki peringkat pertama di Indonesia, jika di kaitakan dengan persaingan dalam industri jasa dimana pangsa pasar yang semakin besar terutama dari sisi bisnis online serta tingkat persaingan semakin tinggi dengan munculnya perusahaan - perusahaan baru pengiriman paket, maka perusahaan JNE Express tentunya harus mampu menumbuhkan loyalitas pelanggannya guna tetap bertahan dalam persaingan di era saat ini.

Berdasarkan uraian tersebut, hipotesis dalam penelitian ini antara lain (1) Kepercayaan berpengaruh signifikan terhadap kepuasan pelanggan. (2) Kepercayaan berpengaruh signifikan terhadap loyalitas Pelanggan. (3) Kualitas Pelayanan berpengaruh signifikan terhadap kepuasan pelanggan. (4) Kualitas Pelayanan berpengaruh signifikan terhadap loyalitas pelanggan. (5) Kepuasan berpengaruh signifikan terhadap loyalitas pelanggan.

Adapun rumusan msalah pada penelitian ini adalah apakah kepercayaan dan kualitas pelayanan berpengaruh terhadap kepuasan pelanggan? Apakah kepercayaan, kualitas pelayanan, dan kepuasan berpengaruh terhadap loyalitas pelanggan?

Tujuan dari penelitian ini adalah untuk mengetahui pengaruh kepercayaan dan kualitas pelayanan terhadap loyalitas pelanggan pengguna jasa pengiriman paket pada PT. JNE Express Cabang Jember dengan kepuasan sebagai variabel intervening.

\section{Metode}

\section{Rancangan Penelitian}

Berdasarkan uraian latar belakang dan rumusan masalah diatas rancangan penelitian ini menggunakan penelitian yang diklasifikasikan sebagai explanatory research.

\section{Jenis dan Sumber Data}

Jenis data dalam penelitian ini adalah data cross section. Sumber data pada penelitian ini adalah data primer dan data sekunder. Data primer dalam penelitian ini didapat dari penyebaran kuesioner kepada pelanggan pengguna jasa pengiriman paket PT. JNE Express Cabang Jember. Sedangkan data sekunder dalam penelitian ini bersumber dari buku - buku literatur manajemen pemasaran, jurnal, skripsi terdahulu, dan internet. 


\section{Populasi dan Sampel}

Populasi dalam penelitian ini adalah semua pelanggan PT. JNE Express Cabang Jember yang pernah melakukan pengiriman paket. Pengambilan sampel menggunakan teknik purposive sampling. Menurut Ferdinand (2002:51) menyatakan bahwa dalam melakukan pengukuran sampel tergantung pada jumlah indikator dikalikan 5 (lima) sampai 10 (sepuluh). Berdasarkan pada jumlah indikator yang ada sebanyak 15 dikalikan dengan angka 8 (delapan) yaitu sebanyak 120 responden.

\section{Metode Analisis Data}

Penelitian ini menggunakan metode analisis jalur/Path Analysis.

\section{Hasil dan Pembahasan}

\section{Hasil}

\section{Karakteristik Responden}

Berikut ini disajikan statistik deskriptif untuk masing-masing variabel yang digunakan dalam penelitian ini dan data tentang karakteristik responden. Berikut ini disajikan statistik deskriptif untuk masing-masing variabel yang digunakan dalam penelitian ini dan data tentang karakteristik responden. Data yang digunakan dalam penelitian ini meliputi data-data sebagai berikut: Usia, Jenis Kelamin, dan Frekuesi Pemakaian. Data deskriptif responden sebagai berikut.

Tabel 1. Karakteristik Responden Berdasarkan Usia

\begin{tabular}{ccc}
\hline Usia (Tahun) & Frekuensi & Persentase \% \\
\hline$<21$ & 18 & 15 \\
$21-25$ & 39 & 32.5 \\
$26-30$ & 31 & 25.8 \\
$31-35$ & 23 & 19.1 \\
$>35$ & 9 & 7.6 \\
\hline Jumlah & 120 & 100 \\
\hline
\end{tabular}

Sumber: data primer diolah, 2017.

Tabel 1 menunjukkan bahwa responden yang berumur 21 25 tahun merupakan responden dengan persentase terbanyak sejumlah 39 orang $(32.5 \%)$. Hal ini mampu menjelaskan bahwa yang berumur antara 21 - 25 tahun sering melakukan pengiriman paket di JNE Express Cabang Jember yang ratarata mahasiswa dan kalangan pengusaha muda yang kebanyakan menggunakan jasa pengiriman paket JNE Express Cabang Jember sebagai sarana pengiriman dalam bisnis online yang mereka lakukan. Sedangkan responden dengan rata - rata usia 35 tahun keatas merupakan responden dengan persentase paling sedikit. Hal ini berkaitan pada usia tersebut seseorang jarang melakukan bisnis online.

Tabel 2. Karakteristik Responden Berdasarkan Jenis Kelamin

\begin{tabular}{ccc}
\hline Jenis Kelamin & Frekuensi & Persentase $\%$ \\
\hline Laki-laki & 52 & 43.4 \\
Perempuan & 68 & 56.6 \\
\hline Jumlah & 120 & 100 \\
\hline
\end{tabular}

Sumber: data primer diolah, 2017.

Tabel 2 menunjukkan bahwa jumlah responden yang paling banyak adalah responden yang berjenis kelamin perempuan yaitu sebanyak 68 orang $(56.6 \%)$. Hal ini mengindikasikan bahwa perempuan sering melakukan bisnis online seperti onlineshop yang dipasarkan ke seluruh Indonesia, dengan menggunakan jasa pengiriman paket pada JNE Express Cabang Jember.

Tabel 3. Karakteristik Responden Berdasarkan Frekuensi Pemakaian

\begin{tabular}{ccc}
\hline Frekuensi & Frekuensi & Persentase \% \\
Pemakaian & & \\
\hline $2-4$ kali & 14 & 11.6 \\
$5-7$ kali & 26 & 21.7 \\
$8-10$ kali & 49 & 40.8 \\
$>10$ kali & 31 & 25.9 \\
\hline Jumlah & 120 & 100 \\
\hline
\end{tabular}

Sumber: data primer diolah, 2017.

Tabel 3 menunjukkan bahwa responden dengan frekuensi pemakain 8-10 kali merupakan responden dengan persentase terbanyak yaitu sebanyak 49 orang $(40.8 \%)$. Hal ini berkaitan dengan adanya bisnis online yang banyak dilakukan oleh kalangan muda mudi membuat kebutuhan akan jasa pengiriman barang semakin meningkat, sedangkan responden dengan frekuensi 2-4 kali dengan persentase paling sedikit, hal ini berkaitan karena reposnden yang frekuensi 2-4 kali hanya menggunakan jasa pengiriman JNE Express Cabang Jember untuk keperluan pribadi.

\section{Analisis Data}

Analisis Jalur (Path Analysis)

Tabel 4. Hasil Koefisien Pengaruh Langsung

\begin{tabular}{ccccc}
\hline \multicolumn{2}{c}{ Standarized } & \multirow{2}{*}{ Sig } & A & Ket \\
\cline { 1 - 2 } \multicolumn{1}{c}{ Jalur } & Beta & & & \\
\cline { 1 - 2 } $\mathrm{X} 1 \rightarrow \mathrm{Z}$ & 0.427 & 0.000 & 0.05 & Signifikan \\
$\mathrm{X} 2 \rightarrow \mathrm{Z}$ & 0.127 & 0.020 & 0.05 & Signifikan \\
$\mathrm{X} 1 \rightarrow \mathrm{Y}$ & 0.375 & 0.001 & 0.05 & Signifikan \\
$\mathrm{X} 2 \rightarrow \mathrm{Y}$ & 0.345 & 0.000 & 0.05 & Signifikan \\
$\mathrm{Z} \rightarrow \mathrm{Y}$ & 0.232 & 0.022 & 0.05 & Signifikan \\
\hline
\end{tabular}

Sumber: hasil analisis jalur/path, 2017.

Berdasarkan Tabel 4, Untuk menganalisis jalur pertama dapat dijelaskan bahwa antara Kepercayaan $\left(\mathrm{X}_{1}\right)$ dengan Kepuasan (Z) memiliki pengaruh yang signifikan. Hal tersebut dapat diketahui dengan hasil nilai signifikan yaitu 0.000 lebih kecil dari $\alpha=0.05$. Jalur kedua antara Kualitas Pelayanan $\left(\mathrm{X}_{2}\right)$ dengan Kepuasan $(Z)$ memiliki pengaruh yang signifikan yaitu sebesar 0.020 lebih kecil dari $\alpha=0.05$. Jalur ketiga antara Kepercayaan $\left(\mathrm{X}_{1}\right)$ dengan Loyalitas (Y) memiliki pengaruh yang signifikan yaitu sebesar 0.001 lebih kecil dari $\alpha=0.05$. Jalur keempat antara Kualitas Pelayanan $\left(\mathrm{X}_{2}\right)$ dengan Loyalitas (Y) memiliki pengaruh yang signifikan sebesar 0.000 yaitu lebih kecil dari $\alpha=0.05$. Jalur kelima antara Kepuasan (Z) dengan Loyalitas (Y) memiliki pengaruh yang signifikan yaitu sebesar 0.022 


\section{Pembahasan}

\section{Pengaruh Kepercayaan Terhadap Kepuasan Pelanggan}

Berdasarkan hasil analisis jalur pada Uji t terhadap hipotesis pertama (H1) dapat dilihat bahwa kepercayaan berpengaruh terhadap kepuasan dengan melihat taraf signifikansinya yaitu sebesar 0.000. Hubungan yang ditunjukkan oleh koefisien regresi adalah positif, artinya semakin baik Kepercayaan maka Kepuasan akan semakin meningkat (H1 diterima). Hasil penelitian ini mendukung teori Kotler 2007 (dalam Yoga 2015), mengatakan bahwa kepercayaan adalah kesediaan perusahaan untuk bergantung pada mitra bisnis. Apabila kualitas periferal semakin baik, yang ditunjukkan dengan fasilitas yang lengkap serta lokasi yang strategis, maka kepuasan pelanggan akan semakin meningkat. Hal ini terjadi karena kualitas periferal adalah penilaian pelanggan terhadap suatu kualitas yang menyebabkan suatu barang atau jasa menjadi pilihan dan menjadi kualitas pendukung.

Fenomena yang terjadi pada JNE Express Cabang Jember seperti peristiwa hilangnya paket, salah alamat pengiriman dapat mempengaruhi kepuasan pelanggan JNE Express Cabang Jember. Sehingga JNE Express Cabang Jember harus berusaha menjaga dan meningkatkan kepercayaan pelanggannya. Kepercayaan dapat diberikan JNE Express Cabang Jember dengan cara menjaga interaksi dengan pelanggan, memberikan pelayanan sesuai harapan pelanggan, serta memiliki kemampuan dalam memberikan informasi secara rinci kepada pelanggan. Sedangkan hasil penelitian yang sudah dilakukan yang mengacu pada jawaban responden tentang variabel kepercayaan dengan indikator kemampuan berinteraksi dengan jawaban setuju persentase $45.8 \%$ hal ini mengindikasikan bahwa interaksi antara pelanggan dan JNE Express Cabang Jember sudah baik yang dilakukan secara langsung, artinya bahwa kemampuan berinteraksi JNE Express Cabang Jember dalam membangun kepercayaan dengan pelanggan sangatlah berpengaruh terhadap kepuasan pelanggan, dimana hal tersebut di landasi dari banyaknya pengalaman karyawan dalam melakukan interaksi dengan pelanggan yang dapat membangun kepercayaan antara pelanggan dengan JNE Express Cabang Jember.

Aspek kedua dari indikator kepercayaan yaitu dapat dipercaya, responden menjawab setuju sebesar $50 \%$ hal ini dikarenakan paket pelanggan sudah mampu dikirim sesuai dengan tujuan pelanggan, Artinya bahwa JNE Express Cabang Jember memberikan pelayanan sesuai dengan apa yang disampaikan kepada pelanggannya, terbukti jika JNE Express cabang Jember memberikan pelayanan pengiriman paket dengan jangka waktu 1-2 hari maka JNE Express Cabang Jember harus mengirim paket pelanggan tersebut tidak boleh lebih dari 2 hari dan hal ini berpengaruh terhadap kepuasan pelanggan. Kondisi pelanggan yang menginginkan ketepatan waktu pengiriman paket mengharuskan JNE Express Cabang Jember lebih disiplin waktu. Tentunya pelanggan akan semakin puas dengan perusahaan yang memahami dan mengerti keinginan mereka.

Aspek ketiga dari indikator kepercayaan yaitu sikap terbuka, merupakan kemudahan yang diberikan JNE Express Cabang Jember kepada pelangganya dalam hal memperoleh informasi tentang produk pelayanan yang ada pada JNE Express Cabang Jember yang diberikan secara langsung maupun melalui media internet yaitu website. Dengan memberikan kemudahan terhadap pelanggannya, maka pelanggan akan merasa bahwa mereka benar-benar dihormati dan diberikan pelayanan yang maksimal, yang nantinya dapat berpengaruh terhadap kepuasan pelanggan. Dalam indikator sikap terbuka ini mendaptkan nilai jawaban responden setuju dengan persentase tertinggi yaitu $70 \%$.

Hasil penelitian ini sejalan dengan penelitian sebelumnya yang dilakukan oleh Yoga (2015) yang menyatakan bahwa Kepercayaan berpengaruh positif terhadap Kepuasan. Jadi dapat disimpulkan bahwa Kepercayaan berpengaruh positif terhadap Kepuasan pelanggan PT. JNE Express Cabang Jember.

\section{Pengaruh Kepercayaan Terhadap Loyalitas}

Hasil analisis jalur pada Uji t terhadap hipotesis kedua $(\mathrm{H} 2)$ dapat dilihat bahwa kepercayaan berpengaruh terhadap loyalitas dengan melihat taraf signifikansinya yaitu sebesar 0.001 . Hubungan yang ditunjukkan oleh koefisien regresi adalah positif, artinya semakin baik Kepercayaan maka Loyalitas akan semakin meningkat (H2 diterima). Penelitian ini juga mendukung teori Akbar dan Parves (2009) menyatakan bahwa kepercayaan juga sebagai dasar untuk membangun dan memelihara hubungan jangka panjang.

Menurut populasi berdasarkan usia 21-25 tahun yang merupakan usia paling dominan loyal pada konsumen JNE Express Cabang Jember. Hal ini mendapat pengaruh besar dari terjalin interaksi yang baik antara perusahaan dan pelanggan, JNE Express Cabang Jember membuktikan bahwa pelayanan yang diberikan pelanggan sebanding dengan apa yang diharapkan oleh pelanggan, serta pemberian informasi layanan paket pengiriman yang dapat memudahkan pelanggan. Menurut populasi berdasarkan jenis kelamin perempuan mendominasi dalam menaruh kepercayaan yang berpengaruh terhadap loyalitas, hal ini dikarenakan perempuan cenderung ketika harapannya dipenuhi, maka perempuan cenderung akan menggunakan jasa tersebut dan enggan untuk beralih ke perusahaan sejenis lainnya. Sedangkan menurut populasi frekuensi pemakaian, pelanggan yang paling dominan rata-rata menggunakan jasa pengiriman paket di JNE Express Cabang Jember sebanyak 8-10 kali, hal ini menjelaskan bahwa pelanggan sudah mengarah kepada loyalitas terhadap jasa pengiriman JNE Express Cabang Jember. Terakhir berdasarkan populasi pekerjaan, wiraswasta cenderung menaruh kepercayaan terhadap JNE Express Cabang Jember, hal ini wiraswasta di Jember cenderung tidak memiliki pekerjaan tetap dan tidak terikat oleh waktu, mereka berbisnis lewat internet, dengan luasnya pasar melalui internet tersebut, membuat para wiraswasta yang melakukan bisnis online tersebut membutuhkan jasa pengiriman paket baik dalam kota maupun luar kota, dengan adanya kepercayaan yang timbul antara JNE Express Cabang Jember dengan pelanggannya membuat para pelangganya menggunakan kembali jasa pengiriman paket di JNE Express Cabang Jember.

Kepercayaan dengan indikator kemampuan berinteraksi, dapat dipercaya, sikap terbuka berpengaruh positif dan signifikan terhadap loyalitas, hal ini menjelaskan bahwa kemampuan JNE Express Cabang Jember dalam berinteraksi membangun kepercayaan terhadap pelanggan akan berdampak pada sikap loyal, hal tersebut ditunjukkan dengan 
minatnya pelanggan terhadap layanan baru yang ditawarkan oleh JNE Express Cabang Jember. JNE Express Cabang Jember yang membuktikan bahwa perusahaan tersebut dapat dipercaya oleh pelanggannya memberikan kepuasan yang berdampak pada loyalitas, hal tersebut tunjukkan dengan pelanggan yang melakukan rekomendasi kepada teman dan orang terdekatnya bahwa di JNE Express Cabang Jember memberikan hadiah kepada pelanggan yang mempunyai JNE loyalty card. Sedangkan sikap terbuka yang tunjukkan JNE Express Cabang Jember kepada pelangganya yaitu melalui pemberian informasi langsung dan melalui media sosial maupun website, dengan adanya kemudahan pelanggan memperoleh informasi tentang pelayanan pengiriman paket mereka, pelanggan semakin percaya dan mau menggunakan kembali jasa pengiriman paket JNE Express Cabang Jember.

Hasil penelitian ini sejalan dengan penelitian sebelumnya yang dilakukan oleh Yoga (2015) yang menyatakan bahwa Kepercayaan berpengaruh positif terhadap Loyalitas. Jadi dapat disimpulkan bahwa Kepercayaan yang timbul antara perusahaan dan pelanggan dapat berpengaruh positif terhadap Loyalitas pelanggan PT. JNE Express Cabang Jember.

\section{Pengaruh Kualitas Pelayanan Terhadap Kepuasan Pelanggan}

Hasil analisis jalur pada Uji t terhadap hipotesis ketiga (H3) dapat dilihat bahwa kualitas pelayanan berpengaruh terhadap kepuasan dengan melihat taraf signifikansinya yaitu sebesar 0.020. Hubungan yang ditunjukkan oleh koefisien regresi adalah positif, artinya semakin baik Kualitas Pelayanan maka Kepuasan akan semakin meningkat (H3 diterima). Penelitian ini mendukung teori yang dikemukakan oleh Kotler (2007:67), kualitas pelayanan ialah kemampuan perusahaan dalam memuaskan kebutuhan secara tersirat dipengaruhi oleh adanya keseluruhan ciri serta sifat suatu pelayanan. Sedangkan pelayanan mengandung pengertian bahwa suatu hal yang tidak berwujud dan tidak juga berakibat kepemilikan dari manfaat yang diberikan oleh suatu pihak kepada pihak lain. semakin tinggi tingkat kualitas pelayanan yang diberikan oleh JNE Express Cabang Jember kepada pelanggan, maka akan semakin tinggi pula tingkat kepuasan yang dirasakan oleh pelanggan.

Berdasarkan pengujian hipotesis bahwa variabel kualias pelayanan yang terdiri dari 5 indikator yaitu ruangan yang digunakan, kecepatan waktu pelayanan, membantu kesulitan, keramahan karyawan, perhatian berpengaruh positif dan signifikan terhadap kepuasan pelanggan. Artinya bahwa dengan kondisi ruangan yang tertata rapi dan bersih mampu membuat pelanggan yang datang ke JNE Express Cabang Jember merasa nyaman. Penataan furniture dan peralatan di dalam ruangan serta menjaga kebersihan ruangan merupakan sesuatu hal yang harus tetap dipertahankan dan dijaga oleh JNE Express Cabang Jember agar pelanggan tetap terpuasakan.

Aspek kedua dari indikator kualitas pelayanan adalah kecepatan waktu pelayanan. Dengan JNE Express Cabang Jember mampu memberikan kecepatan pelayanan terhadap pelanggan maka akan memberikan pengaruh terhadap kepuasan pelanggan dalam menggunakan jasa pengiriman paket, karena paket pelanggan sudah mampu diantar dengan tepat waktu. Pelanggan tidak akan merasa bingung dengan waktu pengiriman paketnya, karena JNE Express Cabang
Jember sudah memberikan pilihan paket dan jumlah jam maupun hari dalam daftar pilihan pengiriman paket. Aspek ketiga dari indikator kualitas pelayanan adalah membantu kesulitan. tidak semua pelanggan akan terpuaskan oleh pelayanan yang diberikan oleh JNE Express Cabang Jember, untuk pelanggan yang tidak puas, mereka kemungkinan akan melakukan keluhan. Dengan JNE Express Cabang Jember menjawab keluhan pelanggan dengan memberikan solusi yang tepat, maka pelanggan tersebut akan terpuaskan. Dengan pelanggan memberikan keluhan merupakan aset bagi perusahaan. Banyak cara yang dilakukan oleh JNE Express Cabang Jember dalam memudahkan pelanggannya memberikan masukan, salah satunya yaitu dengan menyediakan kotak saran maupun kontak person yang dapat dihubungi.

Aspek yang keempat dari indikator kualitas pelayanan adalah keramahan karyawan. Perusahaan jasa pastilah akan mengandalkan kualitas pelayanan guna memberikan kesan postif kepada pelanggannya. JNE Express Cabang Jember selalu berusaha memberikan kepuasan kepada pelanggannya melalui pelayanan karyawannya. Karena di era saat ini pelanggan lebih mudah sensitif, hal ini dikarenakan persaingan dengan banyaknya perusahaan sejenis yang membuat pelanggan berfikir bahwa ketika pelanggan dibuat kecewa oleh JNE Express Cabang Jember maka mereka bisa kapan saja berpindah kepada perusahaan yang sejenis lainnya, maka dari itu JNE Express Cabang Jember harus tetap mempertahankan keramahan karyawannya agar pelanggan tetap puas terhadap pelayanan dan jarang memberikan keluhan. Aspek kelima dari indikator kualitas pelayanan adalah perhatian. JNE Express Cabang Jember yang bergerak dalam industri jasa expedisi sangat erat sekali dengan waktu pengiriman. Tentunya JNE Express Cabang Jember dalam uapaya untuk memuaskan pelanggannya, harus memberikan perhatian yang membuat pelanggan merasa diperhatikan. Ketika pelanggan mau melakukan pengiriman paket, pihak JNE Express Cabang melalui karyawannya, menanyakan tentang paket apa dan untuk keperluan apa yang akan dikirim oleh pelanggan, dengan begitu karyawan JNE Express Cabang Jember dapat memberikan perhatian berupa masukan tentang pilihan layanan paket yang cocok untuk pelanggan tersebut.

Hasil penelitian ini sejalan dengan penelitian sebelumnya yang dilakukan oleh Nurul Yoga (2015) yang menyatakan bahwa Kualitas Pelayanan berpengaruh positif terhadap Kepercayaan. Jadi dapat disimpulkan bahwa Kualitas Pelayanan berpengaruh positif terhadap Kepuasan PT. JNE Express Cabang Jember.

\section{Pengaruh Kualitas Pelayanan Terhadap Loyalitas}

Hasil analisis jalur pada Uji t terhadap hipotesis kempat (H4) dapat dilihat bahwa kualitas pelayanan berpengaruh terhadap loyalitas dengan melihat taraf signifikansinya yaitu sebesar 0.000 . Hubungan yang ditunjukkan oleh koefisien regresi adalah positif, artinya semakin baik Kualitas Pelayanan maka Loyalitas akan semakin meningkat (H4 diterima). Penelitian ini juga didukung teori (Kotler, 2009:83) Pelayanan mengandung pengertian bahwa suatu hal yang tidak berwujud dan tidak juga berakibat kepemilikan dari manfaat yang diberikan oleh suatu pihak kepada pihak lain. Semakin tinggi tingkat kualitas pelayanan yang diberikan oleh JNE Express Cabang Jember kepada pelanggan, maka akan semakin tinggi 
pula tingkat kepuasan yang dirasakan oleh pelanggan dengan kepuasan yang dirasakan oleh pelanggan maka akan mengarah kepada loyalitas pelanggan. Tujuan utama perusahaan jasa tidak hanya mencari profit tetapi di era saat ini haluan perusahaan lebih menekankan kepada bagaimana menciptakan dan meningkatkan loyalitas bagi pelanggannya. Salah satu cara dalam rangka menciptakan loyalitas bagi pelangganya ialah dengan kualitas pelayanan. Dengan memberikan kualitas pelayanan yang sesuai dengan harapan pelanggan akan berdampak pada loyalitas pelanggan. Bisa digambarkan bahwa apabila perusahaan memberikan kualitas pelayanan yang baik, maka akan mempunyai pengaruh yang positif terhadap kinerja perusahan.

Hasil dari penelitian yang dilakukan menunjukkan bahwa kualitas pelayanan yang diberikan oleh JNE Express Cabang Jember terbukti sudah sesuai dengan apa yang diharapkan oleh pelanggan. Pelanggan juga menemukan pelayanan yang ramah dari karyawan JNE Express Cabang Jember, hal ini akan menstimulus pelanggan untuk loyal terhadap JNE Express Cabang Jember. Penataan dan kebersihan ruangan dan kecepatan waktu merupakan bentuk pelayanan yang menyeluruh yang diberikan JNE Express Cabang Jember kepada pelanggannya. Selain itu, pada setiap pelayanan pasti terdapat kekurangan yang dirasakan oleh pelanggannya, maka dari itu JNE Express Cabang Jember menyediakan kotak saran, dan kontak persen yang dapat dihubungi oleh pelanggan yang hendak melakukan keluhan, dengan hal ini akan mempu memperbaiki pelayanan yang berdampak baik bagi JNE Express Cabang Jember.

Kualitas pelayanan dengan indikator ruangan yang digunakan, kecepatan waktu pelayanan, membantu kesulitan, keramahan karyawan, perhatian berpengaruh positif dan signifikan terhadap loyalitas. Hal ini menunjukkan bahwa ruangan yang digunakan sudah mampu membuat pelanggan mau kembali menggunakan jasa pengiriman paket di JNE Express Cabang Jember, dengan hal tersebut membuat pelanggan tentunya akan merekomendasikan kepada pelanggan lainnya. Rekomendasi yang dilakukan seorang pelanggan juga dipengaruhi oleh kecepatan waktu pelayanan yang diberikan oleh JNE Cabang Jember. Pelanggan yang memiliki keluhan paket yang belum sampai pada waktunya diberikan penjelasan oleh karyawan JNE Express Cabang Jember pelanggan dilihatkan posisi keberadaan paketnya melalui aplikasi internet sehingga pelanggan tidak perlu lagi kawatir paketnya hilang. Hal tersebut melihatkan bahwa pelayanan karyawan di JNE Express Cabang Jember sudah menunjukkan keramahan yang dibuktikan para karyawan ini memperlakukan dengan mencoba memahami kemauan para pelanggan yaitu memberikan ketenangan kepada pelanggan serta memberikan jaminan atas paket pelanggan, sehingga pelanggan akan merekomendasikan jasa pengiriman paket di JNE Express Cabang Jember kepada pelanggan lainnya.

Hasil penelitian ini sejalan dengan penelitian sebelumnya yang dilakukan oleh I Gede Yogi Pramana (2016) yang menyatakan bahwa Kualitas Pelayanan berpengaruh positif terhadap Loyalitas. Jadi dapat disimpulkan bahwa Kualitas Pelayanan berpengaruh positif terhadap Loyalitas PT. JNE Express Cabang Jember.

\section{Pengaruh Kepuasan Terhadap Loyalitas}

Hasil analisis jalur pada Uji t terhadap hipotesis kelima (H5) dapat dilihat bahwa Kepuasan berpengaruh terhadap Loyalitas dengan melihat taraf signifikansinya yaitu sebesar 0.022 . Hubungan yang ditunjukkan oleh koefisien regresi adalah positif, artinya semakin baik Kepuasan maka Loyalitas akan semakin meningkat (H5 diterima). Penelitian ini didukung oleh teori Kotler, (2007:233), bahwa kepuasan adalah perasaan senang atau kecewa seseorang yang muncul setelah membandingkan antara persepsi/kesannya terhadap kinerja (atau hasil) suatu produk dan harapan - harapannya. Berdasarkan definisi tersebut bahwa kepuasan merupakan harapan dari konsumen kepada perusahaan tentang produk atau jasa yang diberikan oleh perusahaan. kepuasaan atau ketidakkepuasaan pelanggan adalah respon pelanggan terhadap evaluasi ketidaksesuaian (disconfirmation) yang dirasakan antara harapan sebelumnya dan kerja actual yang dirasakan setelah pemakaiannya. Artinya bahwa pelanggan membandingkan antara sebelum dan sesudah membeli jasa di JNE Express Cabang Jember tersebut, apabila mampu membuat pelanggan puas, dampak yang diterima perusahaan ialah keuntungan semakin besar melalui penjualan yang meningkat karena pelanggan yang sering membeli jasa perusahaan tersebut.

Berdasarkan variabel kepuasan menggunakan indikator kepuasan atas pelayanan, sesuai dengan harapan, jarang memberikan keluhan berpengaruh positif dan signifikan terhadap loyalitas, artinya jika kepuasan yang dirasakan pelanggan di JNE Express Cabang Jember semakin tinggi maka pelanggan akan semakin loyal terhadap perusahaan. Hal ini ditunjukkan dengan pelanggan yang puas terhadap pelayanan yang diberikan oleh karyawan JNE Express Cabang Jember mulai dari menanyakan tujuan pengiriman paket, serta ditunjukkan pilihan layanan paket yang sesuai dengan keperluan pelanggan. Tidak hanya itu, pelayanan di JNE Express Cabang Jember juga dirasakan oleh pelanggan ketika sikap karyawan yang ramah serta sabar dalam menghadapi keluhan pelanggan. Para pelanggan yang puasa mereka bahkan menyatakan akan menggunakan jasa pengiriman paket di JNE Express Cabang Jember, tidak hanya itu mereka juga akan membeli jasa lain yang di tawarkan oleh JNE Express Cabang Jember. Hal lain juga mempengaruhi kepuasan pelanggan yaitu sesuai harapan pelanggan, artinya bahwa apa yang menjadi harapan pelanggan untuk menggunakan jasa pengiriman paket di JNE Express Cabang Jember sudah sesuai dengan harapannya. Hal ini ditunjukkan ketika pelanggan menginginkan tepat waktu dalam proses pengiriman barang, JNE Express Cabang Jember sudah mampu membuktikannya dengan memberikan pelayanan pengiriman paket tepat waktu serta sesuai dengan tujuan pengiriman paket pelanggan.

Pelanggan yang puas terhadap jasa pengiriman paket di JNE Express Cabang Jember enggan melakukan keluhan, karena para pelanggan yang terpuaskan tersebut justru cenderung melakukan rekomendasi, karena pelanggan di JNE Express Cabang Jember didominasi oleh perempuan, mereka lebih mudah melakukan rekomendasi kepada teman-teman lainnya bahkan tidak hanya menceritakan kepada teman-teman 
lainnya, mereka juga melakukan pembelian atau mencoba jasa lain yang ditawarkan oleh JNE Express Cabang Jember. JNE Express Cabang Jember harus tetap menjaga dan meningkatkan kepuasan pelangganya untuk tetap mempertahankan loyalitas pelanggannya, dibuktikan oleh JNE yang tetap berusaha menjaga pelangganya dengan menghadirkan JNE Loyalty Card.

Hasil penelitian ini sejalan dengan penelitian sebelumnya yang dilakukan oleh Nurfina (2016) yang menyatakan bahwa Kepuasan berpengaruh positif terhadap Loyalitas. Jadi dapat disimpulkan bahwa Kepuasan berpengaruh positif terhadap Loyalitas PT. JNE Express Cabang Jember.

\section{Simpulan}

Hasil pengujian analisis jalur atas pengaruh kepercayaan terhadap kepuasan menunjukkan hubungan yang positif. Ini membuktikan bahwa semakin baik kepercayaan maka akan meningkatkan kepuasan. Hasil pengujian atas pengaruh kepercayaan terhadap loyalitas pelanggan menunjukkan hubungan yang positif. Ini membuktikan bahwa semakin baik kepercayaan maka akan meningkatkan loyalitas. Hasil pengujian atas pengaruh kualitas pelayanan terhadap kepuasan menunjukkan hubungan yang positif. Ini membuktikan bahwa semakin baik kualitas pelayanan maka akan meningkatkan kepuasan. Hasil pengujian atas pengaruh kualitas pelayanan terhadap loyalitas menunjukkan hubungan yang positif. Ini membuktikan bahwa semakin baik kualitas pelayanan maka akan meningkatkan loyalitas. Hasil pengujian atas pengaruh kepuasan terhadap loyalitas menunjukkan hubungan yang positif. Ini membuktikan bahwa semakin baik kepuasan maka akan meningkatkan loyalitas.

\section{Referensi}

Akbar dan Parvez. 2009. Impact of Service Quality, Trust, and Customer Satisfaction Loyalty. ABAC Journal. Vol.29.(1).

Ferdinand. 2002. Struktural Equation Modelling dalam Penelitian Manajemen Edisi 2. Semarang: Badan Penerbit Universitas Diponegoro.

I Gede Yogi Pramana. 2016. Pengaruh Kualitas Pelayanan Terhadap Kepercayaan Nasabah Dan Loyalitas Nasabah Bank Mandiri Cabang Veteran Denpasar Bali. E-Jurnal Manajemen Unud, 5 (1): 706-733.

Kotler, Philip, 2006. Manajemen Pemasaran Edisi Kesebelas. Jakarta: PT. Indeks.

Kotler, Philip. 2007. Manajemen Pemasaran di Indonesia: Analisis Perencanaan, Implementasi dan Pengendalian. Jakarta: Salemba Empat.

Kotler, Philip. 2009. Manajemen Pemasaran. Jakarta: Erlangga

Kotler dan Keller. 2009. Manajemen Pemasaran Edisi Ketiga Belas Jilid 1. Jakarta: Erlangga.

Nurfina. 2016. Analisis Pengaruh E-Commerce Strategy, Service Performance Terhadap Loyalitas Pelanggan dan Kepuasan Pelanggan Sebagai Variabel Intervening. Journal Of Management. 2.(2).

Reichheld dan Schefter. (2000). E-Loyalty: Your Secret Weapon on the web. Harvard Businnes Review. 78 (4): 105-113.

Steven. 2014. Analisis Pengaruh Kualitas Layanan Terhadap Loyalitas Pelanggan Dengan Kepuasan Dan Kepercayaan Pelanggan Sebagai Variabel Intervening Pada Asuransi Jiwa Manulife Indonesia Surabaya. Jornal Of Manajemen. 2. (1).

Yoga. 2015. Pengaruh Kualitas pelayanan dan Kepercayaan Terhadap Loyalitas Pelanggan Dengan Kepuasan Pelanggan Sebagai Variabel Intervening. Studi Kasus Pelanggan di PT Indo Samudera Perkasa Semarang. Jurnal Of Management. 4. (4). 